\title{
Key Competences, Education for Sustainable Development and Strategies for the Development of 21st Century Skills. A Systematic Literature Review
}

\author{
Juan Carlos González-Salamanca ${ }^{1}$, Olga Lucía Agudelo ${ }^{2}$ and Jesús Salinas ${ }^{3, *(\mathbb{D})}$ \\ 1 District Secretary of Education, Francisco José de Caldas Industrial Technical Institute, \\ Electricity and Electronics, Bogotá 111061, Colombia; jcgonzalez81@misena.edu.co \\ 2 Faculty of Education, University of Santander, Bucaramanga 050020, Colombia; olga.agudelo@cvudes.edu.co \\ 3 Institute for Educational Research and Innovation, The University of the Balearic Islands, 07122 Palma, Spain \\ * Correspondence: jesus.salinas@uib.es; Tel.: +34-9-7117-2405
}

Received: 28 October 2020; Accepted: 8 December 2020; Published: 11 December 2020

check for updates

\begin{abstract}
Skills needed to be successful in the world have changed, and there is a gap between those learned at school and those required to function at work and in society. A broader range of skills is required to learn, communicate, collaborate, and solve problems in digital environments. Twenty-first century skills have been identified by UNESCO, OECD, and others as competences required for a sustainable future of the knowledge society. The aim was to learn the design principles involved in the incorporation of these skills into the curriculum, find out possible ways to teach and assess them, and examine how this process could be personalized using Information and Communications Technology (ICT). A literature review was carried out through a qualitative metasynthesis, which identified 43 studies that met the inclusion criteria. From the in-depth analysis, it can be seen that although the incorporation of 21st century skills into the curriculum, teaching methodologies, and the use of ICT are all recurrent themes, there is still a need for further research into the design and implementation of new instruments for assessment and the ways in which the teaching-learning process can be personalized.
\end{abstract}

Keywords: 21st century skills; personalized learning; curricular co-design; ICT; learning paths

\section{Introduction}

Current and future citizens face new challenges, such as increasing complexity and uncertainty; growing individualization and social diversity; expanding economic and cultural uniformity; the degradation of the ecosystem services on which they depend and mounting vulnerability and exposure to natural and technological hazards [1]. Addressing complex challenges and current and future uncertainty are at the heart of Agenda 2030 and are therefore the focus of the 17 Sustainable Development Goals (SDG) originally conceived by the UN, with particular emphasis on SDG4: "Ensure inclusive and equitable quality education and promote lifelong learning opportunities for all" [2].

SDGs address critical global challenges, and to overcome them, everyone (youth and adults, men and women, citizens and professionals in all fields) requires key competences that enable them to engage constructively and responsibly with today's world and to actively participate in the necessary transformations. The aim is to promote comprehensive Education for Sustainable Development (ESD) and Education for Global Citizenship (EGC) programs through 21st century skills, focused on providing sustainability education for future generations of professionals $[3,4]$.

The creation of knowledge, as well as its acquisition, validation, and use, must be common to all people as part of a collective social endeavor [1]. On the other hand, some of these skills are 
difficult to teach only by traditional methods, which are still effective to promote learning. These skills must be developed by individuals themselves through action based on personal experience and reflection [4]. Incorporating SDGs into the curriculum requires systemic thinking and interdisciplinary approaches and demands pedagogical innovations that provide interactive, experiential, transformative, and real-world learning [3,5]. Twenty-first century skills are different from 20th century skills, primarily due to the emergence of highly sophisticated information and communications technologies [5].

\subsection{Education for Sustainable Development}

ESD is a comprehensive and transformative education that focuses on content and learning outcomes, pedagogy, and the learning environment. This implies that citizens need the knowledge, skills, values, and attitudes that will enable them to collaborate in sustainable development [3]. ESD requires a transformative, action-oriented pedagogy that promotes autonomous learning, participation and collaboration, problem solving, interdisciplinarity and transdisciplinarity, and linking formal and informal learning. Only these pedagogical approaches will enable the development of the key competences necessary to promote sustainable development in the 21st century [3].

A concept closely related to Education for Sustainable Development (ESD) and Education for Global Citizenship (EGC) is that of the pedagogy of sustainability [6], but this is hardly mentioned in current discourses on education and learning in the context of socio-ecological sustainability and sustainable development. Teaching sustainable development issues is a challenge because it involves knowledge across multiple disciplines, and the 21st century skills are a critical reference point for developing these ambitious profiles of knowledge and skills in students (and also in teachers $[7,8]$ ) expecting that they will become future 'problem solvers', 'agents of change', and 'transition managers' $[4,9,10]$.

In this context, the use of ICT is fundamental in each of the 21st century skills frameworks. Here, the concept of learning incorporates the importance of the individual learner into the process, a focus on deep learning and the transformative power of ICT, all of which lead to the concept of personalized learning [11,12]. Personalized learning requires the connecting power of ICT to develop ways of thinking and learning that liberate and empower the learner.

\subsection{The Development of 21st Century Skills}

There are various conceptions about the 21st century that have been proposed by organizations such as the United Nations Educational, Scientific and Cultural Organization (UNESCO), the Organization for Economic Co-operation and Development (OECD), Partnership for 21st Century Skills (P21), Assessment and Teaching of the 21st Century Skills (ATC21S), etc. All of them have proposed to place 21st century skills at the heart of individual learning. Initiatives range from those whose main concern is preparation for the world of work and future jobs in the idea of maintaining the economy [13-15], to others whose primary focus is a commitment to a sustainable economy and awareness of the importance of the conservation of the planet and its resources $[3,4,8,16]$. While agreeing on the fundamentals, each organization brings in complementary ideas to the concept of 21st century skills.

The term '21st century skills' began to appear in the literature from 1990 onwards. Additionally, around that time the term 'knowledge economy' was coined in reference to a whole new range of jobs that would require skills in working with ideas, people, or systems rather than with physical things [17].

The P21 framework for 21st Century Learning approaches the content knowledge and 21st century themes through the major academic disciplines, and the best way to accomplish this is by transferring the learning of the basic competence and weaving interdisciplinary topics of the 21st century. Another concept suggested by this framework is the importance of learning and innovation skills. Students who want to excel in an increasingly complex working and living environment will learn to focus on 21st century skills such as creativity, communication, and collaboration [13].

The OECD approach has been developed based on two major initiatives: The Definition and Selection of Competences Program (DeSeCo) and the Program for International Student Assessment 
(PISA) [13]. The DeSeCo project aimed to provide a framework that could guide the long-term extension of assessments into new competence domains. DeSeCo uses three groups of key competences: (i) using tools interactively, (ii) interacting in socially heterogeneous groups, and (iii) acting autonomously. The ability of individuals to think for themselves and to take responsibility for their own learning and actions lies at the core of the DeSeCo framework [14].

UNESCO (2015) [1] argues that these types of skills are essential for achieving sustainable development, noting that not all types of education contribute to it. If education only promotes economic growth, it is likely to lead to an increase in unsustainable consumption patterns. Approaching the 21st century skills within the framework of Education for Sustainable Development (ESD) enables students to make informed choices and take responsible actions to foster environmental integrity, economic viability, and a more equitable society for present and future generations $[10,15]$.

\subsection{Strategies for the Development of 21st Century Skills}

This set of competences, which have been termed 'skills for the 21st century', regardless of their specific affiliation, differs from traditional academic skills, since they are not based primarily on content knowledge, but may be considered transversal, multifunctional, and independent of context.

These skills are divided into three main areas [18]: Learning and innovation skills, digital literacy skills, and personal and professional life skills. The 4Cs (communication, collaboration, critical thinking, and creativity) would be included under the area of learning and innovation.

One of the most common is known as $4 \mathrm{C}$ [11], conceptualized as a synthesis of the strong similarities between the proposals put forward by the Ministerial Council for Education, Employment, Training and Youth Affairs in Australia [19], the American Management Association in the United States (USA) in conjunction with Partnership 21 (P21) [20] and AT21CS [16].

Organizations advocating for 21st century skills have broadly consistent frameworks in terms of what should be added to the curriculum, although different groups place emphasis on different areas within the overall skill set. Using the P21 framework as a starting point, for example, groups focusing on technical skills, along with those that promote digital literacy can be found, emphasizing information and communications fluency through technologies as the most important $[5,11]$.

For the OECD [21] meeting the targets of the Sustainable Development Goals, especially those related to connectivity and digital accessibility, will guarantee 21 st century skills. Thus, the OECD's 2019 Skills Outlook report [22] points out that these skills can be reinforced by digital environments, by facilitating the construction by students of their own learning processes at their own pace. P21 also highlights life and career skills, learning and innovation skills, information skills, media and technology, as well as core curricular subjects and 21st century themes [23].

A key element in the application of digital technologies is design flexibility, which responds to the need to promote student-centered pedagogical methodologies. From the moment the student becomes involved, either through co-design or in the configuration of some of the elements, they are effectively taking the design proposed by the teacher and using it as a springboard for the construction of their own personalized learning path [24]. Here the concept of participatory design where closely-related notions that refer to actions of collective creativity and the joint creation of knowledge, such as co-creation, co-production, or co-design converge [25], and on the other hand, autonomous lifelong learning that could be improved by means of flexible learning paths in different contexts, become meaningful [26-28].

\subsection{Purpose of the Study}

The systematic literature review described in the following section aims to determine how 21st century skills are incorporated into the curriculum, what are the design principles, and how these skills are taught and assessed. Along with this, understanding the role of technology and how personalization and student involvement is integrated into these processes. 


\section{Methods}

A systematic literature review has been carried out in the form of a scientific study ensuring transparency and replicability in terms of the steps followed, thus providing a global view of the most important ideas on a topic in a field of research [29].

To achieve the objective, established guidelines are applied for the submission of systematic reviews of the PRISMA statement [30].

This paper presents a literature review using the qualitative metasynthesis method to identify the most relevant studies related to the incorporation into the curriculum, teaching and assessment of the 21st century skills. Qualitative metasynthesis uses rigorous qualitative methods to synthesize and interpret the data in a set of studies. This process consists of six steps [31]:

\subsection{Identify a Specific Research Meta-Question}

The meta-question that guides our metasynthesis can be formulated as follows: What are the research-based design principles that allow the incorporation of 21st century skills into the curriculum and to personalize the teaching-learning process with the support of ICT?

Aspects included that are related to this meta-question are: What are the proposals for 21st century skills curriculum development? What are the most effective methodologies for teaching them? Which instruments allow us to assess them? What is the role of ICT in the development of 21st century skills? Which methodology can be used to personalize and engage students to take ownership of their learning?

\subsection{Perform a Comprehensive Search}

For the search, retrieval, and validation in a systematic and iterative process, the topical, population, temporal, and methodological parameters were defined at the beginning in order to ensure that the highest possible number of relevant articles were retrieved from the databases [31] (see Figure 1).

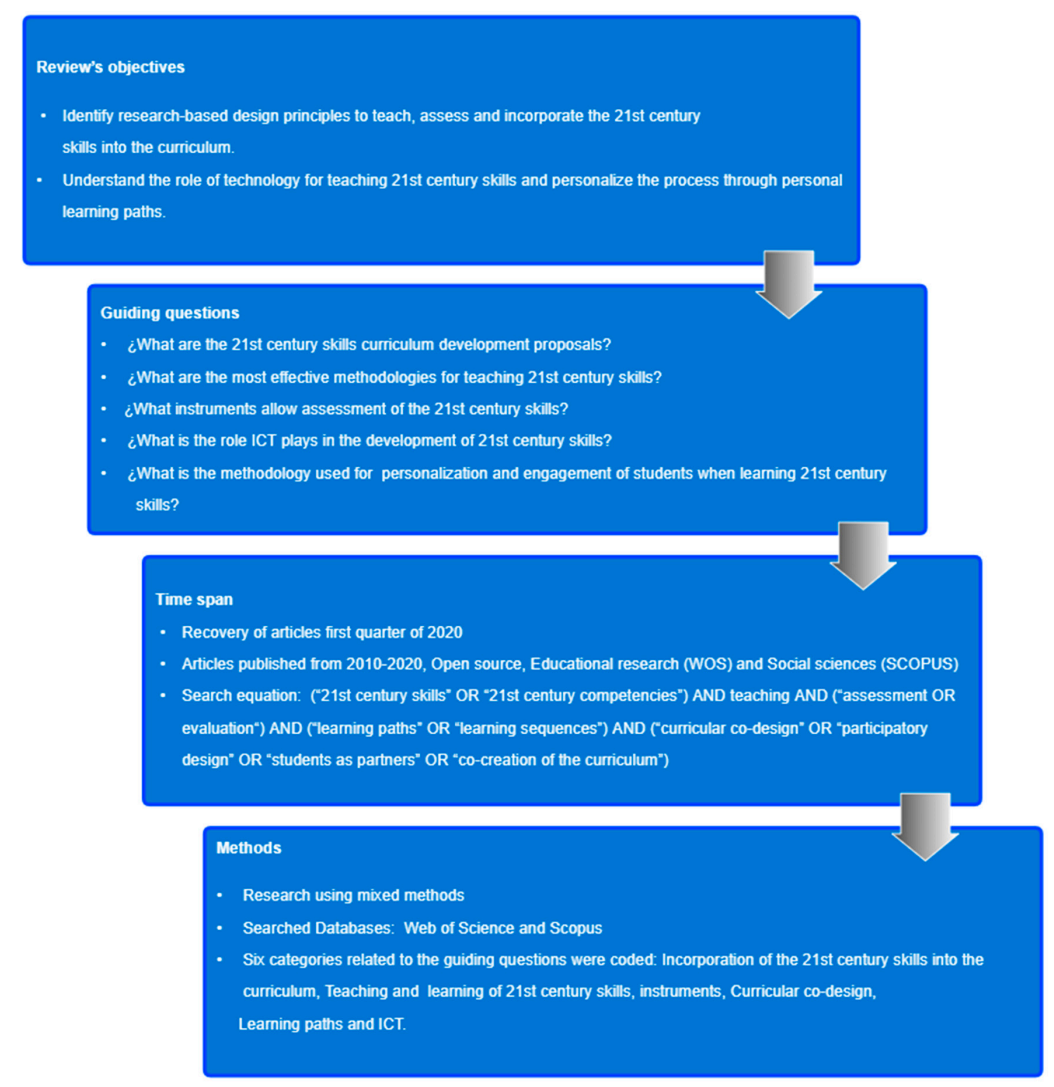

Figure 1. Parameters defined in the study. 
The databases selected for collecting the information were Scopus and the Web of Science (WOS). The search for and selection of articles was conducted between 18 January and 2 March 2020.

A combination of keywords and Boolean operators adapted to each database was used: ("21st century skills" OR "21st century competences") AND teaching AND ("assessment OR evaluation") AND ("learning paths" OR "learning sequences") AND ("curricular codesign" OR "participatory design" OR "students as partners" OR "co-creation of the curriculum"). The search was performed with combinations of at least two of the parameters of the equation. Then the inclusion criteria were applied (Figure 2).

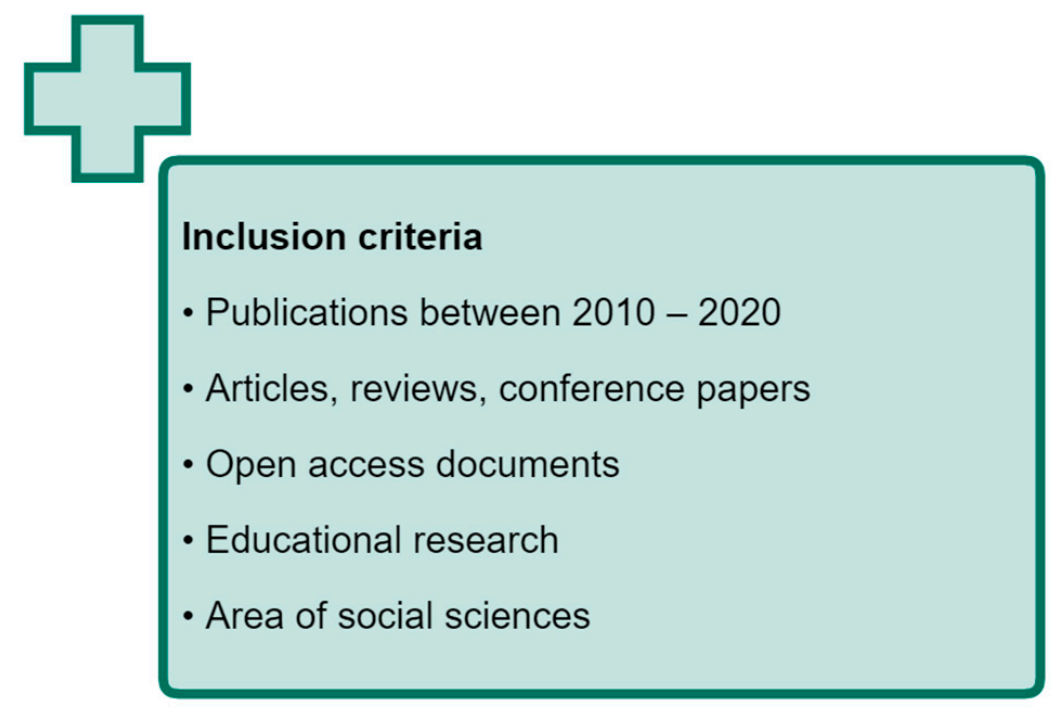

Figure 2. Inclusion criteria.

\subsection{The Selection of Relevant Initial Studies}

To develop the review process, the PRISMA protocol was followed. Figure 3 summarizes the search strategy and review process. The initial search produced a total of 1394 records. After eliminating duplicates, it was reduced to 938 records. When applying the open access inclusion criterion, they were reduced to 494. After selecting only educational research in WOS and social sciences in SCOPUS, 261 remained.

\subsection{Assessing the Quality of the Initially Selected Studies}

After reading the title and abstract of 261 articles, 60 articles remained, and the complete reading of the articles led to 43 to be analyzed.

An in-depth review of the 43 studies was conducted based on in-depth reading looking for evidence related to the guide questions. An analysis matrix was developed with:

1. Year of publication

2. Bibliographical references

3. Key ideas presented in the article

4. Their relationship to the guide questions

5. Text segments with evidence of what was being sought

The analysis matrix is available open access as Supplementary Materials as detailed in the back matter. 

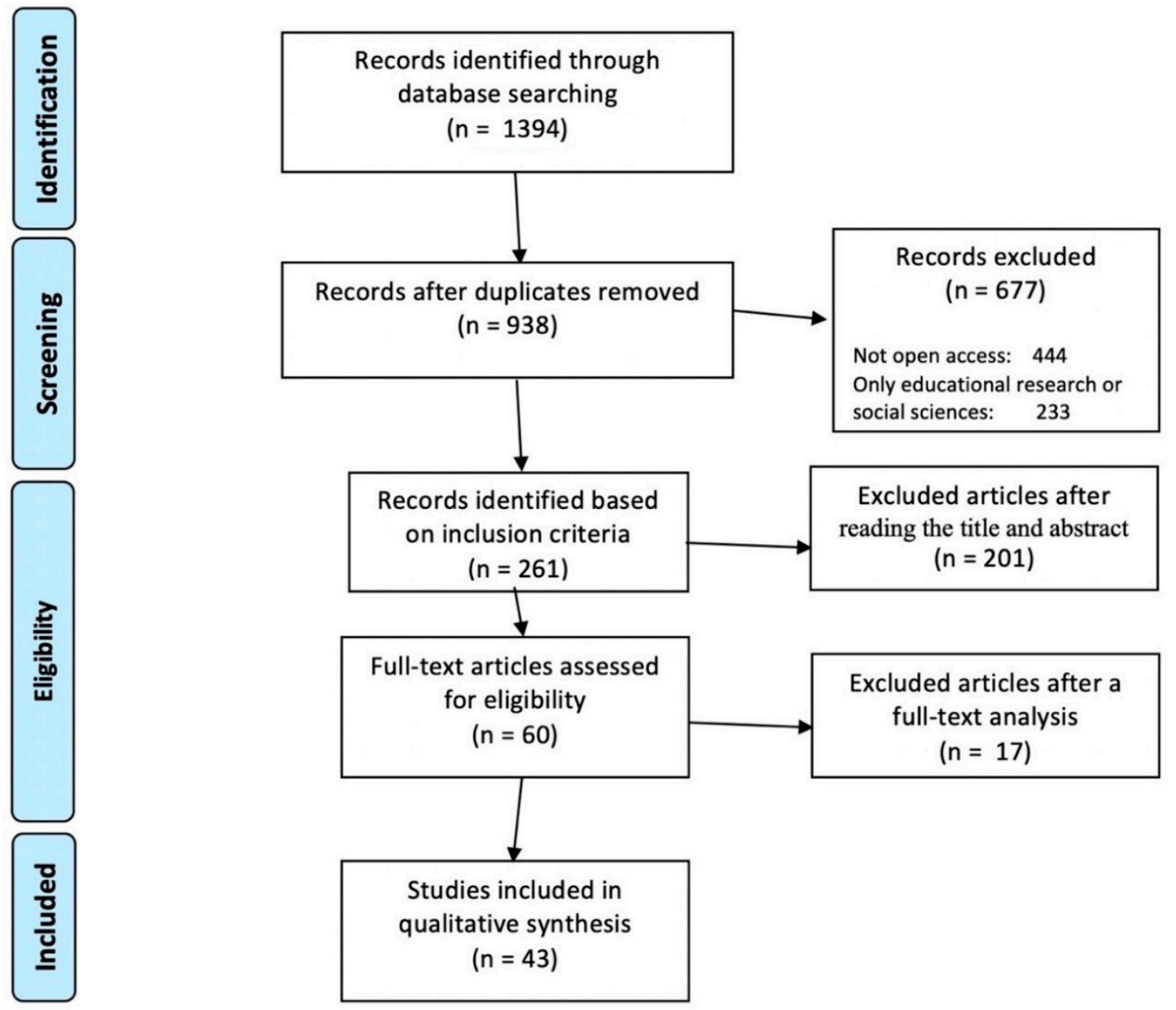

Figure 3. Flow diagram of the review process (following the PRISMA protocol [30]).

\subsection{Summary of Findings from Selected Studies Using Qualitative Techniques}

A qualitative analysis was performed based on the information in the analysis matrix. Six categories related to the guide questions were coded, using NVIVO 12 software. One category was associated with each question, with the exception of the last, which refers to the methodology used for personalization and for getting students involved in their own learning. This was broken down into two parts:

- Curriculum: Gathers all suggestions concerning 21st century skills curriculum development.

- Teaching and learning of the 21st century skills: Brings together all the design principles related to teaching and learning of the 21st century skills.

- Assessment instruments: Draws together text segments describing instruments for assessing the 21st century skills.

- ICT: Seeks to identify everything related to the role that technology plays in the teaching and learning process in 21st century skills.

- Curricular co-design: Refers to the first part of the methodology used for personalization and involvement of students in their own learning.

- Personalized learning paths: Refers to the second part of the methodology used for the personalization and engagement of students in their own learning.

These categories were used in the process of analysis and interpretation giving a distribution summarized in Table 1. 
Table 1. Categories and references.

\begin{tabular}{ccc}
\hline Categories & Number & References \\
\hline Teaching and learning of the 21 CS & $23^{1}$ & {$[11,17,32-52]$} \\
Curriculum & 18 & {$[11,17,33-39,43,44,46-49,52-54]$} \\
ICT & 16 & {$[11,17,33,34,38,39,41,44,46-51,55]$} \\
Assessment tools & 10 & {$[17,34,41,44-47,56-58]$} \\
Personalized learning paths & 8 & {$[11,39,40,43,53,59,60]$} \\
Curricular co-design & 5 & {$[50,54,59-61]$} \\
\hline
\end{tabular}

${ }^{1}$ In some cases, multiple categories are in a single piece of literature.

\subsection{Presentation of the Results Summary}

The phase 6 proposed in [31] presents a summary of the results of the studies addressing the meta-issue of the research. The next section shows how the categories derived from the meta-issue were defined.

\section{Results}

The results of this study are framed within each of the six categories analyzed:

\subsection{Incorporation of 21st Century Skills into the Curriculum}

An effective, relevant curriculum must incorporate important topics aligned with the interests of both students and teachers [32,33]. It must be oriented towards the students' personal, moral, and social development [34].

Communication, collaboration, critical thinking, and problem solving are relevant skills for all, and should be incorporated into the curriculum, taught, and assessed [35]. However, 21st century skills are not part of the curriculum for a variety of reasons; some claim that they are not included because they cannot be taught [17], others allude to a lack of time [36], poor teacher preparation [37], and a lack of strategies for teaching transferable skills [17,38], while others suggest that they have not been implemented effectively [38].

Integrating these skills into the curriculum has been on the agenda of organizations such as the OECD, UNESCO, P21, etc., for some time. Theoretical frameworks have been developed to define these skills, but it is not yet clear how the curriculum should be constructed, although their interdisciplinary nature and the demand for new teaching and assessment methods to integrate them is recognized [38].

Successfully integrating 21st century skills into the curriculum lies, at least in part, in the hands of teachers. However, according to the Foundation for Young Australians [35], only one in ten teachers has recently participated in training that helps students develop transferable skills [35], which suggests that teacher training programs need to incorporate 21st century skills into their own curriculums [37].

Some of the frameworks describing 21st century skills mention possible approaches for their integration into the curriculum, such as: Adding them either as new subjects or as new content within traditional subjects; integrating them as transversal competences, approaching them from existing subjects and promoting the acquisition of broader skills; including them in a new curriculum, transforming the traditional subject structure [38].

When designing the curriculum, it is necessary to take the intended learning outcomes as a starting point and create activities that support the achievement of the objectives established with methodologies such as "constructive alignment" or "backward design" [17]. Developing student capabilities across all subjects should be the goal of a 21st century curriculum [35].

\subsection{Teaching and Learning 21st Century Skills}

Generating a model for incorporating 21st century skills into the curriculum must be grounded in constructivism, as most modern pedagogies [39], with Lev Vygotsky's ideas that originated social 
constructivism as the basis of the model and with the students at the center of the process, reflecting on their experiences [59].

The Zone of Proximal Development is the difference between what the student can do for himself and what he can achieve with the help of a teacher or a more advanced partner. In this model, tools and materials are mediating elements to enhance learning. At the beginning of the 20th century, when Vygotsky wrote his books, the usual tools were mnemonic cards, writing, diagrams, maps, etc. Today we have computers, tablets, smart phones, special purpose applications, and web 2.0 tools that can also help to expand learning [40].

For effective learning to take place, social constructivism proposes certain principles of design for educational activities: The constructive establishes that students' mental schemes must be modified in order to acquire new knowledge; the active refers to the committed participation of the student. The significant has to do with the meaning the student gives to what has been learned. The collaborative affirms that students learn from others, and this interaction leads to greater progress [41,42].

Learning takes place when people reflect on their experiences [43,59]. This leads to the creation of new meanings and emerging knowledge, which is present on subsequent interactions, generating iterative cycles of continuous learning [43]. Each individual builds knowledge in their own individual way, and within a particular context [43].

\subsection{Tools for the Assessment of 21st Century Skills}

Teaching and learning processes include assessment. However, measuring 21st century skills is a difficult process that comes up against numerous obstacles. Most tests that measure 21st century skills focus on basic literacy $[35,44,62]$.

Some instruments for measuring critical thinking do exist, such as the Halpern Critical Thinking Assessment (HCTA), the California Critical Thinking Disposition Inventory (CCTDI), and the Cornell Critical Thinking Test [45], but there is a limited number of instruments to assess performance in skills like communication, collaboration, and problem solving [56,57].

The Association of American Colleges \& Universities developed the VALUE rubrics which separately assess skills such as critical thinking, creativity, oral and written communication, and teamwork [17]. Through PISA, the OECD conducts assessments of ICT literacy and collaborative problem solving, and plans to add intercultural understanding, empathy, and perspective taking as well. More research is needed to measure 21st century skills and to increase global coverage $[58,62]$.

The ATC21S project has developed empirical progressions that combine social and cognitive skills and allow the assessment of individual skills such as communication, collaboration, and critical thinking, or combined skills such as collaborative problem solving, which comprises communication, collaboration, critical thinking, and problem solving. These progressions are rubrics and include indicators that classify the behavior to be observed into levels [35].

\subsection{Technology in 21st Century Skills Teaching Processes}

The role of ICT in the teaching of 21st century skills is multifaceted, and so is analyzed from the following perspectives:

\subsubsection{Context}

Technological literacy refers to the set of skills and knowledge needed to use technology, taking advantage of the possibilities it offers [37], and the ability to solve information, communication, and knowledge problems in digital environments [33].

There are contextual factors that directly impact on ICT literacy, such as socioeconomic status [34,46,47], parental education level [46], and frequency of technology use, which correlates positively with higher scores on ICT skills [34,48]. There is also an impact related to beliefs about their own abilities [46]. Similarly, teachers with better ICT skills and more positive beliefs about their importance $[49,53]$ will be more likely to integrate technology into the classroom effectively [53]. 


\subsubsection{Integration in Educational Processes}

The OECD report [63] argues that the digital divide linked with access to technology is gradually disappearing [34,49], while research suggests another emerging technological divide, linked to skills and the capabilities to take advantage of technology is emerging [34,47].

Access to technological devices is not enough for students to develop their skills or improve their learning, or to lead teachers to change their practices $[7,49,55]$. It needs to be used with purpose, however there are obstacles that prevent it, such as lack of resources, training, or support, and teachers' beliefs and attitudes [49].

Here the training of teachers in ICT becomes really important, in order to increase their skills and knowledge, leading them to use emerging pedagogical models, to understand the importance of ICT in education, and to acquire the confidence and skills to create interactive, engaging, and personalized learning environments [53].

\subsubsection{Skills for the 21 st Century}

Some 21st century skills existed before the advent of modern technologies, and could be taught without technological support $[38,53]$. Critical thinking and problem solving have always been a necessary part of the learning process. Communication and collaboration have been an important part of interpersonal relations for centuries; however, all these skills take on new importance in the digital word of the 21st century [38].

21st century skills comprise 2 subsets: ICT skills—pedagogical and ethical—[48] and higher order skills: Critical thinking, creativity, problem solving, self-regulated learning, communication, and collaboration. Using the former effectively fosters the development of the latter $[11,34]$.

In this sense, the SAMR technology adoption model [64] classifies the use of technology into two stages: Improvement and transformation. Each stage has two elements; in the first, these are substitution and augmentation, and in the second, modification and redefinition. Substitution is concerned with the use of technology in tasks that can be performed without it [11], and at the higher levels deep learning is developed, critical thinking, problem solving skills, effective communication, and collaborative work are promoted [11].

\subsection{Curricular Co-Design}

Co-design or participatory design consists of designing a product or service in collaboration with end users to create innovative solutions and new knowledge [50]. It grew out of the Scandinavian tradition of democratizing workplaces by considering initiatives put forward by workers regarding practices and technology. It is an approach in which researchers and designers develop curricular materials, educational innovations, and interactive technologies such as games and educational software [54].

It is a collective and transformative action aimed at generating new forms of activity with meaningful objectives to stakeholders [54]. It promotes the participation of end users in the development of products in which they have an interest [59]. By participating as partners in design, students benefit, as this provides opportunities for collaboration and communication. They also gain knowledge of the design process and greater self-confidence [61].

Student participation in co-design processes enhances learning [61]. The final product is better as they contribute ideas that are not considered by adult designers [59,60]. Co-design is used in design-based research and aims to transform and improve teaching and learning processes by designing prototypes for specific educational needs [54].

It is suggested that co-design process with student participation should be carried out in three stages [61]: (1) Formulate the learning outcomes, (2) communicate these outcomes, and (3) organize experiences that provide opportunities for learning and reflection. Before beginning the co-design 
process, it is useful to conduct one or more sensitization sessions to reflect on previous learning experiences to find out what they liked and what they did not and be able to better express their ideas.

The material or course in question must include: Feedback, which needs to be clear and precise. Students want to be assessed comprehensively and to understand what they are doing wrong in order to learn from it; rewards based on performance and persistence. Getting good grades motivates and is perceived as a reward for commitment. Content must be delivered in digestible chunks to ensure a correct level of challenge, and an autonomous learning path that fosters their creativity [59].

\subsection{Personalised Learning Paths}

Considering the skills, knowledge, and individual needs of each learner is an approach that has been gaining momentum, even though there is no widely accepted conceptualization of personalized learning or personalized learning paths $[40,47]$. Allowing greater participation in terms of what is to be learned, and to feel identified with the materials and instructional methods underlines the importance of the learner in the learning process [11].

The importance of the student in the learning process, the focus on deep learning and the transformative power of ICT have led to the development of the concept of personalized learning [11,12]. This is based on placing the student at the center of the process; learning is enabled by ICTs and is lifelong [11]. In this approach, individual differences should prevail and be celebrated, rather than being side-lined [40].

Personalized learning is a complex concept that includes individualized teacher-led instructional methods mixed with self-directed learning activities in environments where students have both voice and the power to make choices. It is a multi-layered construct that brings together a wide variety of aspects that have led to different definitions and forms of implementation [47]. Providing flexible and personalized teaching is a major challenge for today's education systems [11,60].

Promoting personal fulfilment and alignment with students' interests is a fundamental part of personalized education [40], seeking a balance between student choice and the scaffolding provided by the teacher generating open learning. In other words, having a voice and choice in the educational environment [47] makes learning a highly individualized, socially constructive, and reflective activity [43].

The Swiss research project PerLen, conducted between 2013-2015, investigated 65 schools using personalized learning concepts. The principal features identified were: (1) Reformulate the timetable to accommodate autonomous learning spaces, with a personalized curriculum which allows students to choose what, how and when to learn; (2) perform cooperative learning tasks; (3) receive counseling to discuss workflow and any difficulties encountered; and (4) monitor progress with digital tools to [47].

Achieving a learning outcome through different pathways or sequences is the fundamental reason for designing a personal learning path. The set of activities to be carried out during an educational cycle forms a learning sequence and the students must select the sequence that best suits their own interests [24]. A learning path is designed around topics organized by levels with increasing degrees of difficulty [39].

\section{Discussion}

From the studies analyzed, there is no consistent idea about which design principles should be used in the proposals for the incorporation of 21st century skills into the curriculum, nor a concrete proposal on how they should be taught and assessed. Concepts closely related to Education for Sustainable Development (ESD) such as Education for Global Citizenship (EGC) or pedagogy for sustainability are hardly mentioned in the articles included in the review. It seems as if the 21st century skills and the goals of sustainable development belong to two different educational discourses.

The incorporation of student personalization and involvement in the design of these learning processes has not been sufficiently researched. As for the role that technology plays in the development of 21st century skills, another of the topics of interest in this work, it takes a prominent place as 
the cornerstone of its development and at the same time as a tool or resource, from the moment it appears as a challenge for learning, for personal and working life today and in the future. It is also clear that teaching these skills requires changes in the curriculum, and new teaching and assessment methods [38].

\subsection{Question 1: What Are the Curriculum Development Proposals for 21st Century Skills?}

Most frameworks recognize the interdisciplinary nature of 21st century skills, but often see them as being complementary to conventional knowledge subjects. Similarly, ESD is often seen simply as an appendix to conventional education and perpetuates the 'rhetoric' of responsible management education [9]. Twenty-first century skills are not defined by topical knowledge, they are defined by their contribution to a problem-solving endeavor, hence the difficulties for a integration into the mainstream curriculum [38].

Ensuring that 21st century skills are not seen as subjects apart from the common core could be a solution. Twenty-first century skills are based on core academic competences, including, for example, critical thinking, academic writing, conducting a literature review, basic research skills, etc. It is difficult to work on some of these competences in conventional contexts [5,17], since they must be developed by individuals themselves through action based on personal experience and reflection [34,35].

Learning content goes hand in hand with developing skills, bearing in mind that cognitive and soft skills are developed simultaneously [33]. Opportunities should be created within disciplines to develop group work, to encourage communication that fosters creativity by solving open-ended problems, and to provide clear and accurate feedback $[4,35,38]$. Problem solving requires creativity, critical thinking, decision making, communication, and collaboration.

Since the reference frameworks are available, the next step to incorporate 21st century skills into the curriculum is for teachers to develop these skills themselves $[33,51,52,62]$. This suggests that teacher training programs should incorporate these skills into their curriculums, (both as content and skills) $[4,8,33,37]$. Guidance should be provided to align technological, pedagogical, and disciplinary elements with new methodological approaches to develop 21st century skills among students $[7,38]$.

\subsection{Question 2: What Are the Most Effective Methodologies for Teaching 21st Century Skills?}

As previously noted, 21st century skill frameworks do not usually reach the most practical aspects of teaching methodologies. Here teachers are the key to bring about changes in classroom practice; where teaching knowledge and skills are essential for restructuring educational processes towards sustainable development $[4,60]$.

To the extent that teachers modify their own practice through the incorporation of active methodologies that place the students at the center of a process based in constructivism [39-43,59], particularly social constructivism that takes the ideas of Lev Vygotsky as the axes of the model, progress will be made in the development of key competences. This process must be achieved by students themselves, with the help of a teacher or a more advanced colleague, always though action, based on experience and reflection $[5,17,34,35,40,59]$.

Effective instruction in transferable skills should provide the opportunity for students to practice and to receive feedback on the particular skill they are trying to strengthen and use that feedback to improve performance. It is not possible to learn to play football by listening to a lecture [17]. Aligning learning outcomes, pedagogical strategies, and tasks that support learning is the key $[3,5]$.

\subsection{Question 3: Which Instruments Allow the Assessment of the 21st Century Skills?}

Assessing 21st century skills is a difficult process and despite the available frameworks is a pending issue, outside of the standardized, fundamental literacy-focused tests $[35,44,62]$. National and international initiatives continue to promote the design and implementation of new assessment instruments. 
Assessing these skills would allow improving the curriculum and strengthening educational quality $[57,58]$.

The most widely used tests for the evaluation of 21st century skills are those developed by PISA [62]. However, there are also several individual tools that assess the skills separately. To perform an observation of skills such as collaboration, communication, critical thinking, and problem solving, the empirical progressions developed by the ATC21S project are an excellent option, as they allow for the observation of social and cognitive skills and their classification into levels [16].

\subsection{Question 4: What Is the Role of ICT in the Development of 21st Century Skills?}

21st century skills refer to the development of personal and social skills of individuals, to share information, values, and knowledge, while participating in and contributing to the development of society. This involves being able to function and act in the digital environment [3,4]. Hence, the role of ICT in the teaching of 21st century skills once again takes on great importance and it is a multifaceted one.

One of the most prominent aspects of this issue is the variety of different factors that directly impact on ICT literacy (socioeconomic level, level of education, etc.) [34,46-48]. For students to be able to develop their skills, aside from access to the devices themselves, there are other obstacles such as a lack of resources, training, support, and also teacher beliefs and attitudes [7,8,11,12,49,55].

Another strand of research refers to the impact of ICT on learning. Although there is some evidence of a positive impact, this does not yet allow for clear conclusions [63]. The use of ICT in the formal and especially in the informal sphere, is considered to have a profound influence on the development of 21 st century skills, both in terms of career and work guidance $[5,33,38,48]$, and in terms of citizenship and sustainable development $[3,9,37,40,44]$.

According to Vygotsky's theory, learning can be widely extended by using mediation tools such as ICT [40]. Using ICTs at the levels of improvement and redefinition proposed by Puentedura's SAMR model for technology adoption [64] allows deep learning and promotes critical thinking, problem-solving, communication, and collaborative work [7,8,11].

There remains the obvious need for teacher's digital competence to facilitate the use of emerging pedagogical models, creating interactive, attractive, and personalized learning environments $[7,11,53]$.

4.5. Question 5: What Methodology Is Used for Personalisation and the Involvement of Students In Learning 21st Century Skills?

The most effective methodologies for teaching 21st century skills $[6,9,59]$ are those that generate participation, reflection, and new knowledge [50,51,54], and one of the ways students participate in learning is through co-design or participatory design $[25,61]$, in which they become involved in a reflective way in order to come up with innovative solutions.

The aim of co-design is to transform and improve teaching and learning processes for specific educational needs by means of collective transformative action based on meaningful objectives for those involved [25,54].

The participation of students in the co-design process makes it possible to improve learning processes [61]. It encourages communication and collaboration among students and enables the design of prototypes to meet specific educational needs $[54,59,60]$. The material or curriculum designed must incorporate feedback, performance-based rewards, content segmentation, and an autonomous learning path [39,52], which leads to personalized learning paths [24].

Personalized learning paths and personalized education allow students a more active role in their learning $[24,40,47]$. Flexible learning responds to the need of promoting pedagogical methodologies that place students at the center of the teaching and learning process $[3,4,10,11,27,28]$, and digital technologies that can support these new ideas for teaching in the form of learning designs $[9,11,12,24,28]$.

The education system should revolve around the student in order to create individual learning experiences in which topics are adjusted in accordance with each individual learner's skills and abilities 
within a pluralistic set of objectives that allows students to be placed in a broad local and global context [40].

Student involvement is fundamental, as indicated by constructivist proposals, either through co-design or through the configuration of some of the elements of that design, the student is appropriating the design proposed by the teacher to build a true personal learning path $[11,24,40]$. Co-design or participatory design provides concepts such as co-creation, co-production, or co-design, which refer to actions of collective creativity and the joint creation of knowledge [25,54]. On the other hand, autonomous learning, which is key in the development of 21st century skills, is improved by means of personalized or flexible paths in different contexts which place the student at the center of the process $[7,24,27,28]$.

\section{Conclusions}

The review presented here includes a number of studies which, although they may not have provided a clear answer to the question posed, contribute to identify and reveal a range of underlying dimensions, such as theoretical constructs to support students in their development and empowerment, or studies dealing with teaching methodologies, the use of ICT, and the personalization of the teaching and learning process. Some topics are not dealt with in sufficient depth in the 43 papers analyzed, perhaps due to the restrictive nature of the selection. It is possible that by including other types of publications such as grey literature or other databases, the results could have been more conclusive.

In relation to the integration of 21st century skills, it seems clear that it can be achieved through the different knowledge disciplines, creating opportunities for practice, feedback, and formative assessment, within a comprehensive curriculum design which involves active methodologies and is based on social constructivism.

The use of technology, as a resource, tool, scaffolding, and as an object of knowledge, is an essential factor in the development of higher order skills such as 21st century skills, especially if it is used at the levels of modification and redefinition. This is true both in terms of the more professional and work oriented aspects, as well as in education for world citizenship and sustainable development.

Elements such as curricular co-design and the creation of flexible learning paths, which allow for the personalization of the educational process, generate autonomy, interest, and the participation of students in their own learning. These are subjects that present a long research journey in terms of methodological formulas for the successful development of 21st century skills.

Teacher's training in 21st century skills and digital competences including digital literacy, management, pedagogical integration, and research, is a key element to enhance the previously mentioned aspects and ensure the dynamism, effectiveness and updating of the educational process.

The review shows that the skills needed for today's students to function at work and in society and to be successful at personal and professional levels must be incorporated into school curricula in a comprehensive and transverse manner, and not in a fragmented way or as a specific subject. Only in this way can they be applied as competences for the knowledge society, thus allowing the full participation of people in democratic processes, inclusive governance, and the achievement of the Sustainable Development Goals.

Although in some cases it is already a consolidation process, the great challenge is to design curricular integration models that, starting from the classic models, take into account the lessons learned and the research carried out in this regard, where active methodologies are involved, enriched with emerging technologies. The proposed methodologies are student-centered and characterized by promoting meaningful learning, interconnection, motivation, flexibility, and autonomy. These are comprehensive proposals that allow students to be part of sustainable development and, at the same time, to be protagonists in the design of their personal learning environments. 
These proposals together with the design and implementation of new assessment instruments, are part of the aims that arise from this review and are seen as a continuation of this research.

Supplementary Materials: The data from the literature review used is available open access at https://is.gd/Ic0QJD.

Author Contributions: Conceptualization, J.C.G.-S., O.L.A., and J.S.; formal analysis, J.C.G.-S. and O.L.A.; funding acquisition, J.S.; methodology, J.C.G.-S. and J.S.; project administration, J.S.; supervision, J.S.; writing-original draft, J.C.G.-S. and O.L.A.; writing-review and editing, J.S. All authors have read and agreed to the published version of the manuscript.

Funding: This research was funded by FEDER/Spanish Ministry of Science and Innovation/State Research Agency/ grant number EDU2017-84223-R.

Conflicts of Interest: The authors declare no conflict of interest.

\section{References}

1. UNESCO. Rethinking Education. Towards a Global Common Good? UNESCO: Paris, France, 2015. Available online: http://unesdoc.unesco.org/images/0023/002325/232555e.pdf (accessed on 5 June 2015).

2. UNESCO. Education 2030 Incheon Declaration and Framework for Action: Towards Inclusive and Equitable Quality Education and Lifelong Learning for all; UNESCO: Paris, France, 2016. Available online: http://www.uis.unesco. org/Education/Documents/incheon-framework-for-action-en.pdf (accessed on 16 November 2018).

3. Lozano, R.; Merrill, M.Y.; Sammalisto, K.; Ceulemans, K.; Lozano, F. Connecting Competences and Pedagogical Approaches for Sustainable Development in Higher Education: A Literature Review and Framework Proposal. Sustainability 2017, 9, 1889. [CrossRef]

4. Anderson, R.D.; Helms, J.V. The ideal of standards and the reality of schools: Needed research. J. Res. Sci. Teach. 2001, 38, 3-16. [CrossRef]

5. Dede, C. Comparing frameworks for 21st century skills. In 21st Century Skills: Rethinking How Students Learn; Bellanca, J., Brandt, R., Eds.; Solution Tree Press: Bloomington, IN, USA, 2010; pp. 51-76.

6. Wals, A.E.; Dillon, J. Foreword. In Educating Science Teachers for Sustainability; Stratton, S., Hagevik, R., Feldman, A., Bloom, M., Eds.; Springer: Frankfurt, Germany, 2015; pp. v-viii.

7. Roig-Vila, R.; Mengual-Andrés, S.; Quinto-Medrano, P. Primary Teachers' Technological, Pedagogical and Content Knowledge. Comunicar 2015, 23, 151-159. [CrossRef]

8. Gisbert-Cervera, M.; Lázaro-Cantabrana, J.L. Professional development in teacher digital competence and improving school quality from the teachers' perspective: A case study. J. New Approaches Educ. Res. 2015, 4, 115-122. [CrossRef]

9. Foucrier, T.; Wiek, A. A Process-Oriented Framework of Competencies for Sustainability Entrepreneurship. Sustainability 2019, 11, 7250. [CrossRef]

10. Wiek, A.; Withycombe, L.; Redman, C. Key competencies in sustainability: A reference framework for academic program development. Sustain. Sci. 2011, 6, 203-218. [CrossRef]

11. Keane, T.; Keane, W.F.; Blicblau, A.S. Beyond traditional literacy: Learning and transformative practices using ICT. Educ. Inf. Technol. 2016, 21, 769-781. [CrossRef]

12. Silva, J.E.; Lázaro-Cantabrana, J.L. The Digital competence of citizens: A growing need in a digitalized society. Edutec. Rev. Electrónica Tecnol. Educ. 2020, 73, 37-50. [CrossRef]

13. Partnership for 21st Century Skills. P21 Framework Definitions; Partnership for 21st Century Skills: Washington, DC, USA, 2009. Available online: http://eric.ed.gov/?q=framework+for+21st+century+learning\&id= ED519462 (accessed on 24 September 2020).

14. Ananiadou, K.; Claro, M. 21st Century Skills and Competences for New Millennium Learners in OECD Countries; OECD Education Working Papers: Paris, France, 2009. [CrossRef]

15. Willard, M.; Wiedmeyer, C.; Flint, R.W.; Weedon, J.S.; Woodward, R.; Feldmand, I.; Edwards, M. The Sustainability Professional: 2010 Competency Survey Report; International Society of Sustainability Professionals: Portland, OR, USA, 2010.

16. AT21CS. What are 21st-Century Skills? The University of Melbourne: Melbourne, Australia, 2012. 
17. Breslow, L. The Pedagogy and Pleasures of Teaching a 21st-Century Skill. Eur. J. Educ. 2015, 50, 420-439. [CrossRef]

18. Trilling, B.; Fadel, C. 21st Century Skills: Learning for Life in Our Times; Jossey-Bass: San Francisco, CA, USA, 2009.

19. MCEETYA. Melbourne Declaration on Educational Goals for Young Australians; Curriculum Corporation: Canberra, Australia, 2008.

20. AMA. AMA 2010 Critical Skills Survey; American Management Association: New York, NY, USA, 2010.

21. OECD. Measuring Distance to the SDG Targets 2019: An Assessment of Where OECD Countries Stand; OECD Publishing: Paris, France, 2019. [CrossRef]

22. OECD. OECD Skills Outlook 2019: Thriving in a Digital World; OECD Publishing: Paris, France, 2019. [CrossRef]

23. Partnership for 21st Century Skills. P21 Common Core Toolkit: A Guide to Aligning the Common Core State Standards with the Framework for 21st Century Skills; Partnership for 21st Century Skills: Washington, DC, USA, 2011. Available online: https://files.eric.ed.gov/fulltext/ED543030.pdf (accessed on 24 September 2020).

24. Salinas, J.; De-Benito, B. Construction of personalized learning pathways through mixed methods. Media Educ. Res. J. 2020, 65, 31-41. [CrossRef]

25. Gros, B.; Noguera, I. Mirando el futuro: Evolución de las tendencias tecnopedagógicas en Educación Superior. Campus Virtuales 2013, 2, 130-140.

26. Janssen, J.; Berlanga, A.J.; Koper, R. Evaluation of the Learning Path Specification. Educ. Technol. Soc. 2011, 14, 218-230.

27. De-Benito, B.; Darder, A.; Salinas, J. Los itinerarios de aprendizaje mediante mapas conceptuales como recurso para la representación del conocimiento. Edutec. Rev. Electrónica Tecnol. Educ. 2012, 39, 1-14. [CrossRef]

28. Agudelo, O.; Salinas, J. Flexible Learning Itineraries Based on Conceptual Maps. J. New Approaches Educ. Res. 2015, 4, 70-76. [CrossRef]

29. Zawacki-Richter, O.; Kerres, M.; Bedenlier, S.; Bond, M.; Buntins, K. Systematic Reviews in Educational Research: Methodology, Perspectives and Application; Springer: Wiesbaden, Germany, 2020. [CrossRef]

30. Moher, D.; Shamseer, L.; Clarke, M.; Ghersi, D.; Liberati, A.; Petticrew, M.; Stewart, L. Preferred reporting items for systematic review and meta-analysis protocols (PRISMA-P) 2015 statement. Syst. Rev. 2015, 4, 1. [CrossRef] [PubMed]

31. Sandelowski, M.; Barroso, J. Handbook for Synthesizing Qualitative Research; Springer: New York, NY, USA, 2007.

32. Lai, E.R. Assessing 21 st Century Skills: Integrating Research Findings; National Council on Measurement in Education: Vancouver, BC, Canada, 2012.

33. Saavedra, A.R.; Darleen Opfer, V. Learning 21st-century skills requires 21st-century teaching. Phi Delta Kappan 2012, 94, 8-13. [CrossRef]

34. Claro, M.; Preiss, D.D.; San Martín, E.; Jara, I.; Hinostroza, J.E.; Valenzuela, S.; Cortes, F.; Nussbaum, M. Assessment of 21st century ICT skills in Chile: Test design and results from high school level students. Comput. Educ. 2012, 59, 1042-1053. [CrossRef]

35. Grainger, P.; Steffler, R.; de Villiers Scheepers, M.J.; Thiele, C.; Dole, S. Student negotiated learning, student agency and General Capabilities in the 21st Century: The DeLorean Project. Aust. Educ. Res. 2019, 46, 425-447. [CrossRef]

36. Harding, S.-M.E.; Griffin, P.E.; Awwal, N.; Alom, B.M.; Scoular, C. Measuring Collaborative Problem Solving Using Mathematics-Based Tasks. AERA Open 2017, 3. [CrossRef]

37. Ahmadi, N.; Besançon, M. Creativity as a Stepping Stone towards Developing Other Competencies in Classrooms. Educ. Res. Int. 2017, 1-9. [CrossRef]

38. Voogt, J.; Erstad, O.; Dede, C.; Mishra, P. Challenges to learning and schooling in the digital networked world of the 21st century. J. Comput. Assist. Learn. 2013, 29, 403-413. [CrossRef]

39. Giordano, D.; Maiorana, F. The Design of an Educational Game for Mobile Devices. In Advanced Technologies, Embedded and Multimedia for Human-centric Computing-HumanCom and \{EMC\} 2013; Huang, Y., Chao, H.C., Deng, D.J., Park, J.J., Eds.; Springer: Dordrecht, The Netherlands, 2014; pp. 221-228. [CrossRef] 
40. Kucirkova, N.; Littleton, K. Developing personalized education for personal mobile technologies with the pluralization agenda. Oxf. Rev. Educ. 2017, 43, 276-288. [CrossRef]

41. Shraim, K. Pedagogical innovation within facebook: A case study in tertiary education in Palestine. Int. J. Emerg. Technol. Learn. 2014, 9, 25-31. [CrossRef]

42. Karnain, R.; Rahman, S.; Surat, S.; Ali, M.T. Usability of M-PA21 module to improve teachers' metacognitive regulation in teaching and application of 21st century basic skills. Int. J. Emerg. Technol. Learn. 2019, 14, 87-105. [CrossRef]

43. Longmore, A.L.; Grant, G.; Golnaraghi, G. Closing the 21st-Century Knowledge Gap: Reconceptualizing Teaching and Learning to Transform Business Education. J. Transform. Educ. 2018, 16, 197-219. [CrossRef]

44. Karchmer-Klein, R.; Shinas, V.H. Guiding principles for supporting new literacies in your classroom. Read. Teach. 2012, 65, 288-293. [CrossRef]

45. De Bie, H.; Wilhelm, P.; Van der Meij, H. The Halpern Critical Thinking Assessment: Toward a Dutch appraisal of critical thinking. Think. Ski. Creat. 2015, 17, 33-44. [CrossRef]

46. Siddiq, F.; Gochyyev, P.; Wilson, M. Learning in Digital Networks-ICT literacy: A novel assessment of students' 21st century skills. Comput. Educ. 2017, 109, 11-37. [CrossRef]

47. Schmid, R.; Petko, D. Does the use of educational technology in personalized learning environments correlate with self-reported digital skills and beliefs of secondary-school students? Comput. Educ. 2019, 136, 75-86. [CrossRef]

48. Almerich, G.; Suárez-Rodríguez, J.; Díaz-García, I.; Orellana, N. Structure of 21st century competences in students in the sphere of education. influential personal factors. Educ. XX1 2020, 23, 45-74. [CrossRef]

49. Ruggiero, D.; Mong, C.J. The teacher technology integration experience: Practice and reflection in the classroom. J. Inf. Technol. Educ. Res. 2015, 14, 161-178. [CrossRef]

50. Androutsos, A.; Brinia, V. Developing and piloting a pedagogy for teaching innovation, collaboration, and co-creation in secondary education based on design thinking, digital transformation, and entrepreneurship. Educ. Sci. 2019, 9, 113. [CrossRef]

51. Häkkinen, P.; Virtanen, T.; Virtanen, A.; Näykki, P.; Pöysä-, J.; Niilo-rämä, M.; Järvelä, S. Finnish pre-service teachers' perceptions of their strategic learning skills and collaboration dispositions. J. Educ. Teach. 2019, 46, 1-16. [CrossRef]

52. Du Toit-Brits, C.; Blignaut, H. Positioning self-directed continuing learning skills in twenty-first century education. Tydskr. Vir Geesteswet. 2019, 59, 512-529. [CrossRef]

53. Willis, R.L.; Lynch, D.; Fradale, P.; Yeigh, T. Influences on purposeful implementation of ICT into the classroom: An exploratory study of K-12 teachers. Educ. Inf. Technol. 2019, 24, 63-77. [CrossRef]

54. Severance, S.; Penuel, W.R.; Sumner, T.; Leary, H. Organizing for Teacher Agency in Curricular Co-Design. J. Learn. Sci. 2016, 25, 531-564. [CrossRef]

55. Pineida, F.O. Competencies for the 21st century: Integrating ICT to life, school and economical development. Procedia-Soc. Behav. Sci. 2011, 28, 54-57. [CrossRef]

56. Scalise, K.; Wilson, M. The nature of assessment systems to support effective use of evidence through technology. E-Learn. Digit. Media 2011, 8, 121-132. [CrossRef]

57. Geisinger, K.F. 21st century skills: What are they and how do we assess them? Appl. Meas. Educ. 2016, 29, 245-249. [CrossRef]

58. Tan, L.S.; Koh, E.; Lee, S.S.; Ponnusamy, L.D.; Tan, K.C.K. The complexities in fostering critical thinking through school-based curriculum innovation: Research evidence from Singapore. Asia Pac. J. Educ. 2017, 37, 517-534. [CrossRef]

59. Nouwen, M.; Schepers, S.; Mouws, K.; Slegers, K.; Kosten, N.; Duysburgh, P. Designing an educational music game: What if children were calling the tune? Int. J. Child-Comput. Interact. 2016, 9-10, 20-32. [CrossRef]

60. Bartholomew, S.R.; Strimel, G.J. Factors influencing student success on open-ended design problems. Int. J. Technol. Des. Educ. 2018, 28, 753-770. [CrossRef]

61. Van Mechelen, M.; Schut, A.; Gielen, M.; Södergren, A.C. Children's assessment of co-design skills: Creativity, empathy and collaboration. In Proceedings of the 18th ACM International Conference on Interaction Design and Children, IDC'19, Boise, ID, USA, 12-15 June 2019; pp. 520-526. [CrossRef]

62. Forum, W.E. New Vision for Education: Unlocking the Potential of Technology; British Columbia Teachers' Federation: Vancouver, BC, Canada, 2015. 
63. Claro, M. Impacto de las TIC en los Aprendizajes de los Estudiantes: Estado del Arte; Naciones Unidas: Santiago, Chile, 2010.

64. Puentedura, R. As We May Teach: Educational Technology, from Theory into Practice. 2009. Available online: http://hippasus.com/blog/archives/25 (accessed on 21 November 2019).

Publisher's Note: MDPI stays neutral with regard to jurisdictional claims in published maps and institutional affiliations.

(C) 2020 by the authors. Licensee MDPI, Basel, Switzerland. This article is an open access article distributed under the terms and conditions of the Creative Commons Attribution (CC BY) license (http://creativecommons.org/licenses/by/4.0/). 